\title{
Using Loseke to examine the influence of laws, myths, and claims making on sex offenders' socially constructed realities
}

\author{
Kyle A. Burgason ${ }^{1}$
}

Received: 21 May 2020 / Revised: 14 September 2020 / Accepted: 21 September 2020 /

Published online: 9 November 2020

(c) Springer Nature Switzerland AG 2020

\begin{abstract}
The realities surrounding sex offenders in the United States can often times be inundated with preconceived and even false certainties. A consequence of such misleading beliefs for sex offenders can be the creation of urban legends and myth that motivated individuals can use to back an agenda and that can bring unintended collateral damage creating false realities for offenders, their families, law enforcement, and the community. This study utilizes Loseke's lens to examine the socially constructed realities in which sex offenders in the United States are forced to live. The history of the treatment of sex offenders is detailed from colonial America through child sexual abuse panic of the 1980s and into the current cyber age. We review laws passed in the 1990s, through the first part of the new millennium, which fueled individuals' fear of sex offenders. Additionally, we explore how claims-makers use myths and socially constructed realities to create social problems for sex offenders, generate public fear and resentment, and pressure policy makers and legislatures to pass laws that promise false hope and false security to communities. Finally, myths associated with cyber sexual offenders are explored. Solutions to combat myths are offered to legitimize the true reality surrounding sex offenders.
\end{abstract}

Keywords Sex offenders $\cdot$ Myths $\cdot$ Realities $\cdot$ Social construction $\cdot$ Claims making

\section{Introduction}

The laws concerning sex offenders seek to achieve protection for citizens of a community, incapacitation of offenders, and possible rehabilitation and a return to society of a productive citizen. The realities surrounding sex offenders can often times be false (Griffin and Miller 2008; Social and Harris 2016), perpetrated by countless

Kyle A. Burgason

burgason@iastate.edu

1 Department of Sociology and Criminal Justice, Iowa State University, 103 East Hall, Ames, IA 50011, USA 
myths concerning the nature of such offenders. These myths can come from a variety of places; media, police, and concerned citizens within a given community. The way these myths or claims are presented to certain audiences is one of the main premises of this study. We utilize Loseke (2003) to examine how claims are constructed and used to form realities about sex offenders. Attention is given to the claims-makers who pitch the ideas, the audience members they are trying to appeal to, and the actors who are involved in both sides of these socially constructed realities.

Additionally, we utilize Loseke's tenants to review the historical context on which the realities are based. Examining how sex offenders were viewed throughout history provides a nuanced understanding of why current laws are structured the way they are. Examining the history of this national problem, we can begin to understand why certain groups of individuals need to construct realities to make sex offenders look more dangerous than they actually are. Finally, we explore the effects that socially constructed realities and laws have had on sex offenders and the community. We offer future implications concerning laws and realities as well as how society can better monitor alleged high-risk offenders without limiting where they can live, work, and attend school without being ostracized.

\section{Theoretical foundation: constructing a social reality}

To have a socially constructed reality, one must start with identifying a social problem, and having the problem gain enough support and backing to be deemed legitimate. Whether the social problem is real or not is often of little consequence, it simply must be believed. Shotter (1993) notes in our arguments about the nature of things we must realize, our statements, whether true or false, are not always about real things, sometimes what they refer to is imaginary. As such, one first must understand what a social problem is, and how individuals go about constructing them.

Spector and Kitsuse (1977) define social problems as the activities of individuals or groups making assertions of grievances and claims with respect to some conditions (75). They agree with Loseke (2003) in that the conditions that lead to the creation of a social problem must meet a certain criterion. The term social problem as defined by Loseke (2003, p. 6) is used to indicate that something is wrong; it refers to conditions evaluated as wrong because they create harm. The second part of the definition is, the condition must be widespread, which means it must hurt more than a few people. The third part of the definition is, the social problem must be able to be changed by humans. The final part of the Loseke definition is, the social problem and conditions should be changed (Loseke 2003).

The two basic conditions that make up a social problem are objective and subjective. Objective conditions are conditions that we can see; they are about measurable and widespread conditions in the environment and they are about the living, breathing people who are hurt by these conditions, or who create these conditions (Loseke 2003). The objective condition is seen as having an intrinsically or malignant nature standing in contrast to a normal society, this makeup of the social problem is usually accompanied by an identification of the conditions that cause the problem and by proposals as to how the problem might be handled (Blumer 1971). The subjective 
conditions are those that cannot be observed. Peoples' ideas about risks matter more than the actual risk measured by objective indicators (Loseke 2003), as noted by Zatz (1987) Chicano Youth Gangs and Crime the Creation of a Moral Panic (Kraska 2004). In actuality, most social problems exist in terms of how they are defined and conceived in a society instead of being an objective condition with a specific objective make up. A social problem does not exist for a society unless it is recognized by the society to exist. In not being aware of a social problem, a society does not perceive it, address it, discuss it, or do anything about it; the problem is just not there (Bulmer 1971). The societal definition gives the social problem its nature, lays out how it is going to be approached, and shapes what is done to correct it (Bulmer 1971). Therefore, whatever people perceive to be a social problem, can in fact become one if they can convince enough individuals in society the problems exist. This can be accomplished by constructing realities where the conditions meet or appear to meet the four-part definition for a social problem. These realities are the result of an intricate process of learning and constructing meanings and definitions of situations through language, symbols, and interactions with other people (Kraska 2004). The social problems and realities are not constructed on their own, they need people to create them, accept them, and allow them to gain power and legitimacy. These people are often referred to as the actors (Kraska 2004; Loseke 2003) in the social problem construction game.

Social constructionism focuses on the process by which a social problem is constructed (Kraska 2004; Spector and Kitsuse 1977). The focus by the criminal justice system on sex offenders did not happen overnight. Criminal justice is a social construction that shifts with intellectual perspective, political influence, social sentiment, cultural values, and the interests of powerful groups in society (Kraska 2004). Some authors describe social constructionism as a dramaturgy, where the actors work hard to construct and maintain an effective impression of themselves through the orchestration of appearances (Kraska 2004). As with any social problem, there are certain actors, known as claims-makers, pushing for the problem and another group of actors, known as the audience, for which the claims are targeted. Before establishing who can be a claims-makers and an audience member for the sex offender constructed realities, one must clearly understand what a claim is and who claims-makers and audiences are, and what they do.

A claim is any verbal, visual, or behavioral statement that seeks to persuade audience members to define a condition as a social problem, or a demand one party makes on another (Loseke 2003; Spector and Kitsuse 1977). Notice no mention of a factual or true statement is contained within the definition. This is what makes the process of constructing social problems and realities different from other problems, objective and empirical evidence need not exist as myths alone can serve as the basis for claims, and is often the case when it comes to sex offenders. We learn about myths from our parents, people in church, socializing with friends, and from teachers. Myths are conceptual schemes that help us interpret reality and organize our thoughts and beliefs about reality. They organize how we see reality; they allow us to adhere to our particular belief system even when contradicted by reality. Thus, myths tell us where society's problems reside, where we should look for solutions, and what solutions are acceptable (Kappeler 2004). As Kappeler states the 
power of myths comes not from their ability to reflect reality accurately but from the power and legitimacy they gain over time, and eventually become truths for many people. Myths can be restricted to specific criminal justice events, always presented as occurring regularly or with increasing frequency (Kappeler 2004) just as the sex offender scare was through the 1980s and into the 1990s by means of claims making.

Claims making is the process of trying to convince the public a particular issue or situation which should be defined as a social problem (Macionis 2005; Spector and Kitsuse 1977). The process begins with the belief that people create meaning because meaning is not inherent in objects; individuals who create this meaning are the claims-makers, or put another way, the people who pitch the claims or myths to the audience (Loseke 2003). The other groups of actors in a social construction drama are the audience members. A social constructionism audience is those people who evaluate the believability and importance of what claims-makers say (Loseke 2003; Spector and Kitsuse 1977). They are critical because a social problem is created only when audience members evaluate claims as being believable and important. How and where the claims and myths are pitched to the audience are important in addressing whether or not the conditions are significant enough to be considered worth the audiences' time. It is important to remember there are multiple claimsmakers pitching multiple claims to audiences at the same time. It is up to the claimsmakers to use the correct pitching techniques and myths to make their particular problem seem like the one warranting the most time and resources. Audiences have a limited caring capacity and only have time to address the most important claims (Loseke 2003). A social problem must gain social endorsement if it is to gain respectability in public discussion. If the social problem does not obtain audience support, it is doomed. Just because a social condition is recognized as crucial by some people in a society does not mean the problem will break through into the area of public consideration. If the social problem fails to obtain legitimacy, it struggles and deteriorates outside of the arena of public action (Blumer 1971). Loseke (2003) suggests using particular motivational frames to make one's claim more enticing. For those fearing sex offenders, a motivational frame could be for the parents and children of the community to appeal to emotion with stories of sexually abused children; however, there is also a chance to appeal to cultural themes. Two possible themes used to construct a motivational frame in the case of parents of children and victims would be through family, and fair play. Fair play, because members of the victims' groups would claim it is unfair their children, as well as themselves, must live in fear because a sexual predator lives in the neighborhood, and is not banned from commuting to libraries, schools, playgrounds, and other places where innocent children convene. The theme of family, because strong families are one of the backbones of our nation, and if a member suffers from a sexual assault, be it an elderly person or a young child, that family's world comes crashing down around them. They lose faith in moral goodness, local law enforcement, and possibly their faith in a higher power. Their motivational frame might be effective if it includes the fact that having someone being violated by a sexual offender affects the entire family negatively. Whether one is a claims-maker for or against sex offenders' rights, it comes down to which side makes the more compelling argument to the policymakers. One need only look to the victims of sex offenders and their families to see the 
claims-makers in this drama, and two of the most popular audiences would have to be communities where sex offenders live and lawmakers.

Innocent children as victims in their home communities are one of the main groups examined when talking about sex offenders. The possible claims-makers in this drama would be parents of children who had been victims of sexual assault by registered sex offenders, or couples with young children that have a registered offender living in their neighborhood. The claims these groups could use would be the emotion-filled story of their own child's, or another child's, experience with a sex offender. Such as the story of 10-year-old Jetseta Gage, a mentally challenged girl who was kidnapped, raped, and murdered at the hands of convicted sex offender Roger Bentley, only to be stuffed into the cabinet below a sink in his trailer (AMW 2006). As Kraska (2004) notes one of the largest, most powerful, and widely accepted claims-makers for criminal justice issues such as sex offenders is the media. The media plays and has played a powerful role in educating the public and influencing public policy in everyday ventures as well as with criminal justice issues. They have a vested interest in the promotion of criminal justice myths because their public is fascinated with sensationalized crime, and crime has become a media product which sells better than any other media commodity (Kappeler 2004). Zatz (1987) notes at the most visible level, social problems and the responses to them are created in part by the media. The media confirm, distort, and structure the conflict between the claims-makers and the deviant group (Kraska 2004), in this case sex offenders. The media are important because they offer claims-makers the largest possible audiences, and because they can reach many different people, as our world gets larger and more mobile we must rely on the media to tell us about it. It is logical to argue claims presented through the media will influence more audience members' understanding of social problems (Loseke 2003). Loseke (2003) notes television becomes particularly important when claims are presented as factual news or based on facts, because these programs encourage viewers to evaluate claims as truthful. On any given day, there are numerous events that are potentially important, but only some become the topic of news shows, producers and editors decide what is and what is not news. They decide how to package the stories in ways that will captivate audience members. On a day-to-day basis, there are predictable biases in how those stories are presented (Loseke 2003).

The history of the influence of media on sexual abuse started in the late 1970s with women recalling repressed memories of being raped when they were children (Jones 1999). Media attention surged through the 1980s particularly after allegations of sexual abuse at McMartin Preschool in California in 1984, the Day School scandal in Fells Acres, Massachusetts in 1984, and the case of New Jersey nursery school worker Kelly Michaels who was absurdly accused of 280 counts of sexual assault in 1987 (Rabinowitz 2003). During these years, the media's focus was on the hidden problem of child sexual abuse, the pain the survivors of such abuse endured, and the need to raise the country's attention to the prevalence of the problem (Beckett 1996). Later in the eighties it was found the aforementioned cases were all hoaxes that were conjured up in the minds of the young children and drawn out by the corrupt tactics used by investigators. The media's focus on sexual abuse ranging from awareness of the problem to false allegations of abuse influenced therapy practice and research 
on the topic (Jones 1999). Jones states research and publications about the problem of sexual abuse went from none in the early 1980 s to 14 articles by 1989 . Publications about sexual abuse leapt to almost 1500 articles from 1995 to 1998 mirroring the emphasis placed on sexual abuse by the media during those years. In terms of therapy, the media's attention on false memories, which were blamed on therapists, had an impact on therapist treatment. The once accepted belief of repressed memories became controversial, causing therapists to become wary of the subject for fear of lawsuits (Jones 1999).

The other audience in which sex offender claims-makers would most likely be pitching to would be lawmakers. The parents of victims and young children as claims-makers would use the aforementioned emotion-filled stories of heartbreak and evil and sensationalized media reports to convince lawmakers the rules regarding sex offenders should be strengthened. Along with legislatures, these emotionfilled stories would likely attract more followers to the movement for the claimsmakers, the more Americans who support a social problem; the more policymakers must be attentive (Loseke 2003). It is strength in numbers form of claims making. Another vital strategy is making the claim at the right time, if one can produce a large number of people during election time all fighting for the same conditions to be recognized, the claims-makers might come to a certain understanding with a particular candidate. Such promises might be, "If this issue is brought before the legislature and gets the laws changed, I can promise you all of these votes" (Loseke 2003, p. 60). You have the offenders arguing the requirements of the laws such as notification and proximity laws are too harsh, and need to be lessened, and in dealing with the same social problem you have the groups of parents, victims, and other supporters trying to persuade the laws are too lax, and need to be strengthened. The actors try to show sex offenders are inherently evil and pose a significant threat to the children of the community. Make the audience members see that the presence of offenders in the community means increased worry to parents, and that having these people live in communities with regular people and children causes an increased threat to the safety and innocence of the children. The aforementioned strategies are the grounds that claims-makers use to pitch the claim.

\section{History of sex offender laws}

Punishments for most crimes throughout the early years of America had religious overtones, and sexual offenses were no exception. Sex crimes were considered sins, and public shaming, flogging, and other degradation ceremonies were common (Friedman 1993; Roth 2005; Shelden 2008). Each region of the country had different degrees of punishment; in the Chesapeake, hard flogging was common, as was being pulled behind a boat until nearly drowning (Roth 2005). In the late eighteenth century and early nineteenth century, the criminal justice system paid less attention to sex crimes as catching and punishing offenders required very precise social conditions, both cultural and structural. Cultural because enough people within the community had to find the act offensive, and structural as laws against sex crimes were difficult to enforce except in small communities (Freidman 1993). In larger 
environments such as New York and Philadelphia, it would be next to impossible to be aware of all sexual crimes taking place, especially those perpetrated in poor working-class communities. Between 1750 and 1796 in the Superior Court of Massachusetts, just $4.3 \%$ of the indictments were for moral and sexual crimes (Freidman 1993).

Following the progressive era and beginning in 1937 in Michigan, were the sexual psychopath laws. By the mid-1970s, more than half of the states had mentally disordered sex offender laws (Masters et al. 2011). These laws allowed the state to confine sex offenders with a mental disease for indefinite periods in a psychiatric hospital instead of corrections facilities. Such laws were abandoned when determinate sentencing came to be popular; however, many called for a return to indeterminate sentencing for violent sex offenders. Many violent sex offenders with fixed sentences were released back into society to reoffend. Current sex offender statutes in most states allow the incarceration period to be extended beyond the original courtmandated because of fear that sex offenders, once released, will reoffend (Masters et al. 2011). As such, offenders are confined for what they are believed likely to do in the future, not for the crime they committed. Even during the early years of the Unites Stated, Loseke's propositions were applicable to sex crimes. There was a wrong, as sexual crimes were viewed as a sin. It was widespread, as each region of the country had its own sanctions. Finally, we can infer that communities tried to change the problem via the punishments described in an attempt to repent or get right with God for the sins committed.

Having violent sex offenders released after serving a determinate sentence led the state of Washington to create the sexually violent predator law (SVP). Under the SVP Act, recidivists may be declared sexually violent predators, confined to a mental health system, and required to stay until considered cured (Masters et al. 2011). Masters et al. states even though preventive detention laws are popular with the general public, their future is uncertain. Under existing law, sexual predators can be freed only after they have been effectively "cured." However, most psychiatrists consider sexual predation to be an anti-social behavior rather than a mental illness and argue it cannot be cured. The Washington State Psychiatric Association called for the repeal of the state's sexual predator law going on record to assert sexual predation is not a mental illness, but falls under criminal conduct (Masters et al. 2011). These doctors declared sexually violent predator laws give offenders what is equivalent to a sentence of life imprisonment. This could lead to slippery-slope mentality in that if recidivism is going to be the basis for determining mental illness and confining offenders in mental institutions, people could call for indeterminate sentences for other repeat felony offenders as well.

Loseke's (2003) tenants are prime display over the course of the next few cases discussed. The wrong is the sexual assault and/or death of Jacob Wetterling, Megan Kanka, Adam Walsh, and Pam Lyncher. Loseke's second proposition is also present as the conditions were most assuredly widespread as these attacks were celebrated cases that made national and international headlines as many others go unreported to national media. In addition, these cases were spread across the entire country. Tenant three is supported in that all of these cases lead to the laws and legislation sought by individual wanting justice for the victims and to prevent such atrocities 
from happening again. Loseke's fourth proposition is a natural progression from her third as it would be rare event to find someone in favor of allowing sexual assaults on innocent victims. As such, this social problem (violent sexual assaults) should be changed to protect potential victims of sexual predators. The reader should keep these tenants in mind as they read through the following cases and visualize the techniques and methods detailed in the previous section that are utilized by claimsmakers to achieve their desired result. Then, one must ask if those ends (socially constructed realities in which many offenders are forced to live) justify the means (the myths perpetuated by some claims-makers).

Prior to 1994, few states required convicted sex offenders to register their addresses with local law enforcement. Major federal statutes dealing with crimes by sexual offenders were named after victims in the cases. The high-profile cases began with the story of young Jacob Wetterling, leading to one of the most important pieces of legislation written to date on laws governing convicted sex offenders, the Jacob Wetterling Act. The Jacob Wetterling Crimes Against Children and Sexually Violent Offender Act was enacted on September 13, 1994 (Reno 1998; National Center Missing Kids). This requires state implementation of a sex offender registration program for persons convicted of a criminal offense against a minor, or a sexually violent offense (42 U.S.C. 14071; Sex Offender Sentencing; Reno 1998). The act requires offenders to be registered for at least ten years as well as update address information when they move and verify the registered address periodically (Reno 1998). The registration alone was not enough, as was revealed just a month and half before the Jacob Wetterling Act was enacted by the murder of 7-year-old Megan Kanka by a released sex offender. The public backlash called for programs to provide the public with information regarding released sex offenders.

Megan Kanka was a 7-year-old girl from Hamilton Township, New Jersey whose family unknowingly lived across the street from Jessie Timmendequas, a twice-convicted sex offender. On July 29, 1994, Timmendequas used the promise of seeing his new puppy to lure young Megan into his home where he proceeded to rape, strangle, and eventually murdered Megan (Masters et al. 2011; National Center Missing Kids; Walker 2006). In 1996, President Clinton signed a federal law that mandated states develop a registry of known sex offenders (National Center Missing Kids). The law requires law enforcement personnel to make information on registered sex offenders available to the public (Reno 1998; Masters et al. 2011; National Center Missing Kids; Sex Offender Sentencing; Walker 2006). While the Jacob Wetterling Act and Megan's Laws were linked directly with keeping children safe from sexual predators, the case of Pam Lychner shows adults also can be the victims of sex offenders.

Pam Lychner was a 36-year-old real-estate agent from Spring Valley Village, Texas who was assaulted by William David Kelley, while selling her home in 1990 (Sex Offender Sentencing). Following the attack Lychner founded "Justice for All," a victims' rights advocacy group that lobbies for tougher sentences for violent criminals (Sex Offender Sentencing). Lychner is also credited with helping to formulate the language for the bill that created a national database that helps track offenders and bears her name. The Pam Lychner Sex Offender Tracking and Identification Act of 1996 requires perpetrators of particularly serious offenses and recidivists be subject to lifetime registration (Reno 1998). 
Despite the implementation and improvements made in the above-mentioned acts, and because mobility has increased significantly in our society (Friedman 1993), many sex offenders continued to offend. The National Center for Missing and Exploited Children reports that numerous offenders failed to comply with registration duties and remain undetected due to the inconsistencies among state laws. Lawmakers recognized this problem along with the burden faced by law enforcement to keep track of the increasing number of offenders and took action. Their solution was based on another high-profile case, Adam Walsh.

Adam Walsh was a 6-year-old boy from Hollywood, Florida who was kidnapped from a store and murdered (Child Search 2003). Consequently, the Adam Walsh Child Protection and Safety Act mandates specific registration requirements for sex offenders in all states (Pub. L. 109-248 2006; National Center Missing Kids). Additionally, the Adam Walsh Act contained details concerning internet sexual abuse, which was quickly becoming widespread in the latter part of the 1990s and into the early part of the new century. It imposed criminal penalties for participation in a child exploitation enterprise, increased penalties for registered sex offenders who committed a felony sex offense against a minor, and prohibited the embedding of deceptive words or images in a website to deceive individuals into viewing obscene material. When the Adam Walsh Act passed, online sexual predators were by no means new, but had become the new norm in soliciting young victims.

\section{The Internet and sex offenders}

Loseke's (2003) arguments are even more salient in the cyber age as computers help to expand the social problem as outline in tenant two. With the advent of the Internet and smart-phones, the problem of sexual assault and exploitation is even more widespread and ubiquitous. While computers and the Internet open a world of possibilities for children, they can be exposed to dangers. Computer telecommunications have become one of the most prevalent techniques used by pedophiles to share illegal photographic images of minors and to lure children into illicit sexual relationships and attempt to sexually exploit children through such online services. As the reader will see going forward, with the greater reach of the Internet, Loseke's third proposition is satisfied as claims-makers and legislatures alike moved feverishly to create and implement more laws and legislation in hopes of changing the national issue. Similar to before, nearly all would agree that this particular problem should be changed as the use of the Internet for sexual exploitation often inclines to put one of the most vulnerable segments of our population as the main targets for predators, children. Some of the techniques used by these individuals to gain trust include attention, affection, kindness, and even sending gifts. These offenders listen to and empathize with children, and use ample time, money, and energy in selecting a victim with the ultimate goal of lowering the child's inhibitions and slowly introducing sexual content into their communications (FBI). Young people are often the victims of a variety of Internet crimes, including solicitations to engage in sexual acts for commercial gain through production and distribution of child pornography or for personal 
gratification (Wolak et al. 2008). In 2001, the Crimes Against Children Research Center at the University of New Hampshire conducted a nationwide Youth Internet Safety Survey through telephone interviews with 1,501 youth 10 to 17 years old. Nearly $20 \%$ received an unwanted sexual solicitation within the last year. Five percent received sexual solicitations that made them upset or afraid; of these victims, $37 \%$ were between the ages 10 and 13 . Another $3 \%$ were asked to allow contact or a meeting offline. The anonymity that the internet affords offenders makes it difficult to get accurate information about them; the true identity, age, and gender of the perpetrators may be different from what they state. Victims believed nearly all the perpetrators were strangers. Two-thirds of all solicitations came from self-described males. Approximately two-thirds of solicitations occurred in chat rooms; $24 \%$ were instant messages. One-quarter of respondents received unwanted sexual material, more boys $57 \%$ compared to girls $42 \%$ (Connelly 2001; Finkelhor et al. 2000). Nearly half of the victims did not tell anyone about the solicitation; of those who did, about a quarter informed a parent. As access to internet technologies expands via increased use of wireless and handheld technologies, monitoring internet communications has become increasingly challenging.

With the emergence of the Internet and other communications innovations creating more opportunity for criminals to solicit victims (Roth 2005), lawmakers and law enforcement were pressured to pass legislation and enforce new laws to help ensure the safety of children online. The Child Pornography Prevention Act of 1996 and the Federal Bureau of Investigation's Innocent Images National Initiative were the results of citizens' requests.

The investigation of a missing juvenile from Prince George's County, Maryland in 1993 by the FBI lead to the discovery of two suspects who had sexually exploited numerous juveniles over the past 25 years and the creation of the Innocent Images National Initiative (IINI). Further investigation into these activities determined adults were routinely utilizing computers to send sexually explicit images to minors and, in some instances, to lure minors into engaging in illicit sexual activity. In 1995, based on information developed during this investigation, the IINI addressed the illegal activities conducted by users of commercial and private online services and the internet.

The Child Pornography Prevention Act of 1996 followed the cases of Megan Kanka and Jacob Wetterling and expanded the federal prohibition on child pornography to include not only pornographic images made using actual children, but also any visual depiction, which is or appears to be of a minor engaging in sexually explicit conduct. As well as any image that is advertised, promoted, presented, described, or distributed in such a manner that conveys the impression or depicts a minor engaging in sexually explicit conduct (U.S. Code. Vol. 182256 1996), making online pornographic images and words of children or to children a strict liability crime. This means all intent has been removed from the criminal act, one either possessed child pornography or did not, as it takes one's intentions completely out of the circumstances and the accused's mental state is irrelevant to guilt or innocence and the chief evidentiary proof rests in the act alone (Nemeth 2004). 


\section{Myths that create the realities}

As Loseke's (2003) propositions have been met, the wrong identified (sexual assault), having widespread effect (numerous victims), changes can be made by people and should be made (laws enacted by claims-makers such as the media, coupled with the resulting legislation). Boundless myths often associated with such offenders, have also been generated, leaving many sex offenders as well as citizens living in socially constructed realities. The current study selected seven myths commonly associated with sex offenders. These myths were drawn from extant literature (ABC News 2006; Davis 2018; Division of Criminal Justice Services 2014; Freeman-Longo 2000), as well from an informal write-in poll asking undergraduate students taking an Introduction to Criminal Justice class at a midsized southern university, to provide two statements they believed true of the master statuses of sex offenders. The myths examined in the current study is by no means an exhaustive list as there exists a wealth of myths surrounding sex offenders and the literature on the topic is overwhelming, as no one article can do full justice to all research on sex offenders. What we have attempted to do is use Loseke's (2003) formulations to demonstrate how each of these myths could be easily create and perpetuate a socially constructed reality in the hands of a motivated claims-maker.

One of the most popular myths is sex offenders have high recidivism rates (Levenson et al. 2007; Social and Harris 2016), which is not supported by empirical research (Harris and Hanson 2004; Helmus et al. 2012; Langan and Levin 2002; Langan et al. 2003; Nieto and Jung 2006; Prentky et al. 1997; Sample and Bray 2003, 2006; Tewksbury et al. 2012). Some studies of treated sex offenders show great variability in recidivism with rates ranging from 0 to $50 \%$ for any offense. Offenders who participated in cognitive-behavioral treatments, which include monitoring in the community by probation or parole personnel suggest increased positive outcomes with recidivism rates ranging from 0 to $18 \%$ (Jones 1999). In a meta-analysis of recidivism studies, Hanson and Bussiere (1998) similarly found that recidivism rates for sex offenders varied considerably, with an average across all studies was 13.4\%. A 2003 study by the U.S. Department of Justice found that within three years of prison release, $5.3 \%$ of sex offenders were arrested for another sex crime. According to the study, sex offenders were less likely than non-sex offenders to be rearrested for any offense: $43 \%$ of sex offenders verses 68\% of non-sex offenders (Beck and Brien 2004). Beck and Brien (2004) note another study conducted in Canada found of 4,724 sex offenders, nearly $75 \%$ had not been charged with another sexual offense after 15 years. According to the available research, the average recidivism rate for sex offenders is low when compared to rates for other crimes. A plausible explanation for such variation might be dependent on the offender and offense characteristics, such as whether or not the perpetrator is a chronic sex offender or someone who was caught on their first offense.

Another prevalent myth concerning sex offenders is that strangers are more likely to sexually abuse children than family members (ABC News 2006; Craun 
and Theriot 2009; Davis 2018; Division of Criminal Justice Services 2014; Freeman-Longo 2000; Levenson and D'Amora 2007; Meloy et al. 2008; Snyder 2000; Vanzile-Tamsen et al. 2005). The reality is of the 500,000 children who are molested each year (Macionis 2005, p. 173), only $10 \%$ of the offenders were strangers, $90 \%$ are family, friends, and people known to the child (Masters et al. 2011). Most of the legislation aimed at controlling sex offenders is focused on the perpetrators being strangers. Children are actually at greater risk of sexual abuse from family members. This myth feeds the fear of parents and communities about strangers within their neighborhoods and their childrens' lives. Many schools are teaching young children the difference between a "good touch" and a "bad touch" and emphasizing the need to tell an adult if a person acts toward them in a manner they feel is wrong (Macionis 2005). On the surface, this seems like a fine idea, but if as the research suggests, the offender is someone the child knows, possibly even a family member or parent, it seems doubtful a child will inform on a family member or parent to another adult.

A third myth surrounding sex offenders is sex offender registries reduce sexual assaults (Agan 2011; Drake and Aos 2009; Duwe and Donnay 2008; Letourneau et al. 2010; Meloy et al. 2007; Prescott and Rockoff 2011; Sandler et al. 2008; Schram and Milloy 1995; Tewksbury and Jennings 2010; Vasquez et al. 2008; Veysey and Zgoba 2010; Zevitz and Farkas 2000; Zgoba et al. 2008) and proximity laws reduce sexual assaults (Barnes et al. 2008; Davey 2006; Duwe et al. 2008; Loney 2008; Meloy et al. 2008; Nieto and Jung 2006; Tregilgas 2010; Zandbergen et al. 2010). In reality, there is little evidence these registries and proximity laws provide effective protection from or act as a deterrent to repeat sex offenders. A sex offender study dealing with 10 states found the passage of sex offender registration and notification laws demonstrated no systematic influence on the number of rapes committed in the states. Most of the states in the sample showed no significant differences in the average number of rapes committed before and after the sex offender laws (Vasquez et al. 2008). The majority of proximity laws require offenders not live within a thousand or several thousand feet of a place where children congregate. This can cause serious problems in some suburban neighborhoods where most of the community has several schools and parks. With offenders being forced from urban areas, they are settling in masses in the suburbs of larger cities where many families live. Polk County Iowa Chief Deputy of Police Bill Vaughn stated since October 10 of 2005, a month after the 2000-foot law was put into action, the number of sexual offenders living in rural Polk County jumped from 76 to 114 as offenders have had to relocate (Dobbs 2005). Offenders are being forced into these clumps similar to "Hoovervilles" pushing them away from their work, families, and homes. Some registered offenders are not abiding by the proximity laws. A study by Tewksbury and Mustaine (2006) found nearly $22 \%$ of a 96-person sex offender sample in Seminole County, Florida was found living within 1000 feet of a playground or park, $14.6 \%$ near an elementary school or day care center. The authors added together the child congregation locations to gauge how many of these locations sex offenders lived near. Data indicated that $31.3 \%$ live near at least one-child congregation location, 14.6 near two locations, and 3.1\% near three locations. They also found out that 12 out of 21 sexual offenders of minors were actually breaking Florida law by living 
near places children congregate. A similar study by Walker et al. (2001) found 48\% of registered sex offenders with child victims lived within 1000 feet of day cares, parks, and schools. It is not just real-world sex offenders that deal with socially constructed realities as the new millennium brought a hyper focus on the internet and social media, the world of online sexual offenders is not without its own myths that have been constructed through claims-makers such as the media and community fear.

A number of the following myths examined in the current study were identified by college students and centered on predators on the Internet. One such myth is about internet sex offenders using deception and trickery to lure small children on the internet into violent sexual meetings. In reality, the majority of internet-originated sex crimes involve adult men who use the internet to meet and seduce underage adolescents into sexual encounters. The offenders use internet communications such as instant messages, e-mail, and chartrooms to meet and develop intimate relationships with victims. In most cases, victims are aware they are conversing online with adults (Wolak et al. 2008). Wolak et al. (2008) note media stories and much of the internet crime prevention information available and suggest it is naïve and inexperienced young children who are vulnerable to online child molesters and it is this that makes them vulnerable. The research indicates, however, by the preteen years, child internet users comprehend the social complexities that exist online at similar levels compared to adults (Wolak et al. 2008; Yan 2006). As children grow older and become more experienced online, they participate with more advanced and interactive internet users, which puts them at greater risk than younger, less experienced children who use the internet in simpler, less interactive ways (Wolak et al. 2008).

Another myth surrounding online sexual victimization identified by students is social networking sites have increased the risk of sexual victimization by online predators. In reality, a study conducted between June and October 2007, consisting of over 400 interviews with police about online sex crimes showed no cases of sex offenders stalking and abducting minors based on information posted on social networking sites (Wolak et al. 2008). The study suggested online predators do not stalk their victims, but actively seek out those victims susceptible to seduction. The study also showed children with profiles on social networking sites, even those trying to meet new people, were no more likely than other children to have uncomfortable or inappropriate contacts with online users.

An additional myth identified by students associated with online sex offenders is online predators are violent pedophiles. The reality is online predators primarily target adolescents as opposed to young children (Wolak et al. 2004). Most online predators do not fit the clinical definition of a pedophile, which is, an individual who is involved in sexually arousing fantasies, urges, or behaviors involving sexual activity with a prepubescent child (APA 2000). Young children were found to be less accessible online compared to teenagers, as young children are more supervised and less likely to respond to the advances of predators because children are less interested in relationships and romance (Wolak et al. 2008). Teenagers with certain characteristics identified as more vulnerable such as those with poor relationships with their parents, who experience loneliness and depression, and who are gay or questioning boys (Wolak et al. 2004). Violence is a rare occurrence in online sex 
crimes. Evidence from Wolak et al. (2008) study suggests online predators are not among the sex offenders who abduct or assault victims. Most online child predators are patient enough to develop relationships with victims and shrewd enough to move those relationships offline (Wolak et al. 2008). It would seem offenders are aware of how to speak to teens to gain and keep their trust through the face-to-face meeting if one was to occur.

The final myth examined here is violent sex crimes against children have increased because of the internet. The reality is several sex crimes and abuse indicators have shown declines during the same period in which the use of the internet has been expanding (Freeman-Longo 2000). From 1990 to 2005, the number of sexual assault cases validated by authorities declined 51 percent (Finkelhor and Jones 2006). For example, the rate of sexual assaults reported by teenagers to the National Crime Victimization Survey declined by 52\% between 1993 and 2005. Additionally, a statewide survey of students in Minnesota also showed declines in sexual abuse during this period (Wolak et al. 2008). Having examined the many myths that have been used to construct the realities of sex offenders, both in real life and online, it is not difficult for one to infer these realities carry with them consequences for the offenders and communities alike.

The construction of social realities based on myths hides contradictions in logic, reality, and carries consequences. Myths may seem harmless, but when associated with the criminal justice system they can have dire consequences for individuals and society (Kraska 2004). One of the major effects of these realities is the laws that establish where sex offenders can live. Using information gathered from census tracts for several counties in Florida, Mustaine et al. (2005) investigated to see if registered sex offenders are more likely to be found in areas with greater social disorganization due to choice or because of stigmatization. The study found negative location characteristics were higher in the census tracts of sex offenders as compared to the rest of the county and the nation. These tracts had higher levels of unemployment, more families living below the poverty line, and the educational level tended to be lower, fewer homes were lived in by owners, housing values were lower, and household income was lower in these census tracts. The study also found that tracts with higher concentrations of sex offenders are more disorganized and less desirable than tracts with lower concentrations of offenders, as these high concentration tracts also had locational, household, and housing characteristics which signified they were more disorganized and disadvantaged places to live (Mustaine et al. 2005). The conclusion reached by this study was communities with characteristics of social disorganization are likely to be the homes of registered sex offenders as offenders live in these areas because they are relegated to such a location.

A similar study conducted by Mustaine et al. (2006) investigated if registered sex offenders currently reside in different locations than they did when arrested, and if offenders did change locations, are their current residences located in more or less socially disorganized locations than their residences at the time of arrest. The study found residential location typically changes after being arrested for a sex offense, and of those who changed locations, half moved to less disorganized areas, and half moved to more socially disorganized areas. Those offenders that lived in less socially disorganized areas originally were more likely to move downward after registration, while 
those who already lived in highly socially disorganized areas were more likely to stay the same or have minimal movement (Mustaine et al. 2006). These studies suggest convicted sex offenders are living in the more socially disorganized areas where quality work and community support tend to be the lowest. The research implies it is not the choice of offenders to live in these areas, but rather many are forced to comply with residency restrictions.

Another problem myth-based realty can bring on sex offenders is aggravation and isolation within a community. This can lead to increased rates of negative consequences for offenders including amplified stress, shame, harassment, job loss, loss of friends, and community harassment or vigilantism (Ackerman and Sacks 2012; Lasher and McGrath 2012). Notably, all of these consequences can be counterproductive insofar as they can lead to reoffending (Freeman and Sandler 2010; Hanson et al. 2009). Some libertarians believe the residency and notification laws are unfair and are an additional punishment beyond the offender serving his or her time. Many offenders are released back into hostile, rejecting communities that have been influenced by media and have few support systems; here the offenders are expected to lead a functional crime-free life while facing difficulty finding housing and employment, threats or harassment, vigilantism, and ostracism from the community (Walker 2006). These constructed realities can take a toll on offenders' families economically, socially, psychologically, and even physically (Levenson and Tewksbury 2009) as well as bring about increased community fear. An evaluation in Wisconsin of community notification laws where people were informed via public meetings resulted in citizens leaving feeling more worried about being victimized than they did when they were unaware of the offender being in neighborhood. Research has also shown the collateral effect of such realities including a decline in home values for homes close to registered sex offenders (Linden and Rockoff 2008; Pope 2008). They have led to extensive financial and resource allocation costs for law enforcement to implement and impose community notification programs (Zgoba et al. 2008). Likewise, probation and parole agencies have had to invest significantly more time to aiding offenders in finding housing and jobs (Zevitz and Farkas 2000). A group often overlooked are the families of offenders. These realities can take a significant toll on them economically, socially, psychologically, and even physically (Levenson and Tewksbury 2009). A final issue worth noting with these realities may well encompass sex offenders who are not violent predators, pedophiles, or rapists, yet still are required to register. This includes individuals who "moon" people, people arrested for urinating in public, and gay and bisexual men convicted of cruising parking lots for sexual partners in public places (Jones 1999). Being aware of the socially constructed realities that sex offenders are living, and examining the history of the laws that the myths and realities help to create, might provide people with a more accurate perspective of the daily obstacles faced by convicted sex offenders.

\section{Discussion/conclusion}

The current study demonstrated the usefulness of using Loseke's (2003) tenants to examine and understand how a motivated group of individuals (claims-makers) can take a true social problem (sexual assaults) and use fear and false narratives to 
establish and perpetuate myths associated with sex offenders, which in turn can lead to the needless fear and suffering of both offenders and citizens.

A possible solution to the problems currently affecting these offenders could be a different type of monitoring. As described above, certain members of society only become more fearful or more likely to be vengeful when they are aware of the sex offenders in their neighborhoods. Only notifying law enforcement of the offender's presence in the neighborhood could possibly reduce both fear and chances of vigilantism. The members of the community would not have to know the identity of the offenders and could continue living their lives without concern. The actions and location of the offenders would be the responsibility of law enforcement and the use of full GPS tracking for all offenders could be employed. The GPS tracking ankle bracelet, which allows law enforcement to track the offender continuously throughout the day, is the most expensive of all tracking bracelets costing around \$7.25 per offender per day (Roos 2005). Although more expensive, this method of tracking would allow officers to know the exact location of offenders throughout the day including when approaching or loitering in a restricted area. However, recent studies have shown no discernible difference in recidivism between GPS-tracked offenders and those that were not tracked via GPS (Levenson and D'Amora 2007; Tennessee Board of Probation and Parole 2007; Turner et al. 2007).

Some conceivable solutions to the online sex offender problems lie not with posting personal information, as millions of children use Facebook, Instagram, and Snap Chat safely. Rather the preventative focus needs to be on controlling and monitoring interactions as online-initiated sexual assaults come about through direct communication between predators and victims (Wolak et al. 2008). This could include talking to children about what types of behavior or signals predators will be looking for, as well as what topics to avoid speaking about online such as loneliness, dislike of one's parents, and sex. Additionally, better investigation and monitoring techniques on the part of computer forensic investigators could serve to quell this problem. As Burgason and Walker (2013) outline as forensic investigators may be able to build a case based on a few EnCase searches and a dump of images, videos, and communication, other cases are more complicated and require a more in-depth investigation (5). As such, the study details the benefits of utilizing optimal foraging theory as a blueprint to track how offenders use the Internet for illicit purposes as "being able to follow an offender from one website to another can aid in establishing timelines of events and in developing profiles, motives, and establishing behavior of the offender. This can aid greatly in complex investigations and prosecutions" (Burgason and Walker 2013).

Laws regarding sex offenders have enticed myths, and these myths have driven the creation of constructed realities that are teeming with problem for offenders, their families, and citizens alike. The claims-makers throughout the past two decades have been successful in getting support from proper audiences, from the media circus surrounding child sex offenses in the 1980s and early 90s, to the passing of the internet pornography and stalking laws. Many social problems tend to lose their appeal after a certain number of years. Sexual assaults are in the minority in that they show no signs of stopping or even slowing down since obsession started in the mid-1990s. In fact, as recently as the summer of 2020 as the 
covid 19 pandemic was in full swing across the nation, a moral panic concerning sex offenders gripped the Upper West Side of Manhattan. To quell the spread of the pandemic, New York City officials started filling boutique hotels with homeless individuals including more than a dozen sex offenders. This did not sit well with some of the "well to do" members of the community and their elected representative who quickly began perpetuating a number of the myths outlined above. One particular city official addressed mounting concerns to her constituents stating, "all level 3 sex offenders have been moved out" and that she was "demanding that all remaining offenders be moved out as well." It was not until days after the offenders had been removed that the official softened her stance contending "I initially took an extreme position and stated that 'no registered sex offenders should be allowed on the Upper West Side'-but that's not realistic. There are around 1,600 registered offenders across Manhattan, and neighborhoods cannot wall themselves off" (McKay 2020). As this incident shows, even today, Loseke's (2003) tenants hold true as the homeless sex offenders were viewed as the social problem that was widespread across the Upper West Side of Manhattan. A number of citizens and official thought the problem should be changed and could be changed by taking action. The claims-makers organized, utilized myths to elicit fear from the community, and were able to have the offenders removed from the area.

Sexualized crime, particularly crimes involving a protected class of citizens such as children, will always garner attention from powerful audiences such as politicians and lawmakers. Furthermore, as long as the media, police, and other claims-makers are willing to use myths to construct realities against sex offenders, they have little chance of convincing enough people they are not as dangerous as perceived. This study identified many of the myths that accompany online sexual predators as well and demonstrated the vitality of Loeske's (2003) from early colonial American clear through to the present-day NYC. From the internet being full of violent pedophiles, to social networking sites being a hot spot for predators to solicit victims, empirical evidence has busted these myths. Solutions have been offered to help to rectify the problem of sex offenders causing fear and stress within society, as well as suggestions in educating individuals, especially children, of the dangers involved in becoming interactive with strangers online.

To change policy, one needs to identify a social problem and gather enough support to bring the said social problem to a public arena. The issue many sex offenders face is finding support for their side of this social problem. While this study alone may not be able to change the minds of enough people, it could serve as a starting point toward a reform of the laws working against sex offenders and many communities. It might also help to quell some of the myths that serve as the building blocks to the socially constructed realities which many sex offenders and their families suffer through on a daily basis. It the authors hope that the current study can be utilized to properly inform the public as to the true nature of sex offenders' lives, as we now have the aid of empirical evidence in support of our argument, while cynics can only cling to their myths. 
Data availability Data sharing not applicable to this article as no datasets were generated or analyzed during the current study.

\section{Compliance with ethical standards}

Conflict of interest K.A.B. receives consulting and expert witness income and travel expenses in criminal litigation relating to criminological assessment of criminal offenders, and receives royalty income from Carolina Academic Press, and Taylor \& Francis/Routledge Press. No direct remuneration is associated with the current study.

\section{References}

ABC News (2006) Myths about sex offenders. https://abcnews.go.com/US/story?id=90200\&page=1

Ackerman A, Sacks M (2012) Can general strain theory be used to explain recidivism among registered sex offenders? Journal of Criminal Justice 40(3):187-193

Adam Walsh Child Protection and Safety Act (2006) Pub. L. 109-248.

Agan A (2011) Sex offender registries: fear without function? J Law Econ 54(1):207-239

America's Most Wanted. Missing data file (2006) Retrieved November, 2010, from http://www.amw.com/ missing_children/brief.cfm?id=31031

Barnes J, Dukes T, Tewksbury R, De Troye T (2008) Analyzing the impact of a statewide residence restriction law on South Carolina sex offenders. Criminal Justice Policy Review 20:21-43

Beck A, Brien P (2004) Trends in the US correctional populations: recent findings from the bureau of justice statistics. In: Haas KC, Alpert GP (eds) The dilemmas of corrections, 3rd edn. Waveland Press, Project Heights, pp 43-63

Beckett K (1996) Culture and the politics of signification: the case of child sexual abuse. Soc Probl 43:57-68

Blumer H (1971) Social problems as a collective behavior. Soc Probl 18:298-306

Burgason K, Walker J (2013) Optimal foraging theory's application to internet sex offender search behavior: a theoretical model for computer forensic investigations. Journal Forensic Investigation 1:1-6

Child Pornography Prevention Act (1996) U.S. Code. Vol. 18, 2256.

Child Search (2003) The Adam Walsh story. https://www.childsearch.us/site1/walshstory.html

Connelly H (2001) Internet crimes against children. Office for Victims of Crime. https://www.ojp.usdoj .gov/ovel

Craun S, Theriot M (2009) Misperceptions of sex offender perpetration: considering the impact of sex offender registration. Journal of Interpersonal Violence 24(12):2057-2072

Davey M (2006) Iowa's residency rules drive sex offenders underground. New York Times.

Davis N (2018) 10 dangerous myths about child sex crime cases. Neal Davis Law Firm. https://www. nealdavislaw.com/blog/sex-crimes/child-sex-myths

Division of Criminal Justice Services (2014) Myths and facts. New York State. https://www.criminalju stice.ny.gov/nsor/som_mythsandfacts.htm

Dobbs K (2005) County molester ban carries costs. The Des Moines Register

Drake E, Aos S (2009) Does sex offender registration and notification reduce crime? A systematic review of the research literature. Washington State Institute for Public Policy, Olympia

Duwe G, Donnay W (2008) The impact of Megan's law on sex offender recidivism: the Minnesota experience. Criminology 46:411-446

Duwe G, Donnay W, Tewksbury R (2008) Does residential proximity matter? A geographic analysis of sex offense recidivism. Criminal Justice and Behavior 35(4):484-504

Federal Bureau of Investigation. A parent's guide to internet safety. https://www.fbi.gov/stats-services/ publications/parent-guide

Finkelhor D, Jones L (2006) Why have child maltreatment and child victimization declined? J Soc Issues 62:685-716

Finkelhor D, Mitchell K, Wolak J (2000) Highlights of the Youth Internet Safety Survey. U.S. Department of Justice. https://www.ojp.usdoj.gov.

Freeman-Longo R (2000) Myths and facts about sex offenders. Center Fort Sex Offender Management. https://oxbowacademy.net/wp-content/uploads/2010/02/mythsfacts.pdf 
Freeman N, Sandler J (2010) The Adam Walsh Act: a false sense of security or an effective public policy initiative? Crim Justice Policy Rev 21:31-49

Friedman L (1993) Crime and punishment in American history. BasicBooks, New York

Griffin T, Miller M (2008) Child abduction, AMBER alert, and crime control theater. Criminal Justice Review 33:159-176

Hanson R, Bussiere M (1998) Predicting relapse: a meta-analysis of sexual offender recidivism studies. J Consult Clin Psychol 66:348-362

Harris A, Hanson R (2004) Sex offender recidivism: a simple question, vol 3. Public Safety and Emergency Preparedness Canada, Ottawa

Hanson R, Bourgon G, Helmus L, Hodgson S (2009) A meta-analysis of the effectiveness of treatment for sexual offenders: risk, need, and responsivity, 2009-01. Public Safety Canada, Ottawa

Helmus L, Hanson R, Thornton D, Babchishin K, Harris A (2012) Absolute recidivism rates predicted by Static-99R and static-2002R sex offender risk assessment tools vary across samples: a metaanalysis. Criminal Justice and Behavior 39:1148-1171

Jacob Wetterling Crimes against Children \& Sexually Violent Offender Registration Act (1994) U.S. Code. Vol. 42, Section 14071.

Jones K (1999) The Media and Megan's law: is community notification the answer? Journal of Humanistic Counseling, Education \& Development 38:80-88

Kappeler V (2004) Inventing criminal justice myth and social construction. In: Kraska PB (ed) Theorizing criminal justice: eight essential orientations. Waveland Press, Inc., Long Grove, pp 167-196

Kraska P (2004) Theorizing criminal justice: eight essential orientations. Waveland Press Inc, Long Grove

Langan P, Levin D (2002) Recidivism of prisoners released in 1994. Bureau of Justice Statistics, Washington, DC

Langan P, Schmitt E, Durose M (2003) Recidivism of sex offenders released from prison in 1994. Bureau of Justice Statistics, Washington, DC

Lasher M, McGrath R (2012) The impact of community notification on sex offender reintegration: a quantitative review of the research literature. Int J Offender Therapy Comp Criminol 56(1):6-28

Letourneau E, Levenson J, Bandyopadhyay D, Sinha D, Armstrong K (2010) Effects of South Carolina's sex offender registration and notification policy on deterrence of adult sex crimes. Crim Justice Behav 37:537-552

Levenson J, D'Amora D (2007) Social policies designed to prevent sexual violence. The emperor's new clothes? Crim Justice Policy Rev 18:168-199

Levenson J, Tewksbury R (2009) Collateral damage: family members of registered sex offenders. Am J Crim Justice 34:54-68

Levenson J, Brannon Y, Fortney T, Baker J (2007) Public perceptions about sex offenders and community protection policies. Anal Soc Issues Public Policy (ASAP) 7:137-161

Linden L, Rockoff J (2008) There goes the neighborhood? Estimates of the impact of crime risk on property values from Megan's laws. Am Econ Rev 98(3):1103-1127

Loney J (2008) Nowhere to go, Miami sex offenders live under bridge. Reuters. https://www.reuters.com/ article/2008/02/05/us-usa-sexoffenders-idUSN0515234320080205.

Loseke D (2003) Thinking about social problems, 2nd edn. Aldine Transaction, New Brunswick

Macionis J (2005) Social problems, 2nd edn. Pearson Prentice Hall, Upper Saddle River

Masters R, Way L, Gerstenfeld P, Muscat B, Hooper M, Dussich J, Pincu L, Skrapec C (2011) CJ realities and challenges. McGraw-Hill, New York

McKay H (2020) Behind the homeless, sex-offenders debacle dividing New York City's once serene upper west side. FOX News. https://www.foxnews.com/us/homeless-sex-offender-debacle-dividingnew-york-citys-upper-west-side

Meloy M, Saleh Y, Wolff N (2007) Sex offender laws in America: can panic-driven legislation ever create safe societies? Crim Justice Stud 20(4):423-443

Meloy M, Miller S, Curtis K (2008) Making sense out of nonsense: the deconstruction of state-level sex offender residence restrictions. Am J Crim Justice 33(2):209-222

Mustaine E, Tewksbury R, Stengel K (2005) Social disorganization and residential locations of registered sex offenders: is this a collateral consequence? Deviant Behav 27:329-350

Mustaine E, Tewksbury R, Stengel K (2006) Residential location and mobility of registered sex offenders. Am J Crim Justice 30:178-191

National Center for Missing and Exploited Children. Sex offenders: history. https://www.missingkid s.com/missingkids/servlet/PageServlet?LanguageCountry=en_US\&PageId=3032. 
Nemeth C (2004) Criminal law. Pearson Prentice Hall, Upper Saddle River

Nieto M, Jung D (2006) The impact of residency restrictions on sex offenders and correctional management practices: a literature review (CRB \# 06-008). California Research Bureau, Sacramento. https ://www.library.ca.gov/crb/06/08/06-008.pdf

Pope J (2008) Fear of crime and housing prices: household reactions to sex offender registries. J Urban Econ 64:601-614

Prentky R, Austin S, Knight R, Cerce D (1997) Recidivism rates among child molesters and rapists: a methodological analysis. Law Hum Behav 21(6):635-659

Prescott J, Rockoff J (2011) Do sex offender registration and notification laws affect criminal behavior? J Law Econ 54(1):161-206

Rabinowitz D (2003) No crueler tyrannies: accusation of false witness, and other terrors of our times. Free Press, New York

Reno J (1998) Megan's law: final guidelines for the jacob wetterling crimes against children and sexually violent offender registration act, as amended. Department of Justice, Office of the Attorney General, Washington, DC

Roos J (2005) Sex offenders aren't tracked continuously. The Des Moines Register

Roth M (2005) Crime and punishment: a history of the criminal justice system. Thomson Wadsworth, Belmont

Sample L, Bray T (2003) Are sex offenders dangerous? Criminol Public Policy 3(1):59-82

Sample L, Bray T (2006) Are sex offenders different? An examination of rearrest patterns. Crim Justice Policy Rev 17(1):83-102

Sandler J, Freeman N, Socia K (2008) Does a watched pot boil? A time-series analysis of New York State's sex offender registration and notification law. Psychol Public Policy Law 14(4):284-302

Schram D, Milloy C (1995) Community notification: a study of offender characteristics and recidivism. Urban Policy Research, Washington State Institute for Public Policy, Seattle. https://www.wsipp.wa. gov/rptfiles/chrrec.pdf

Sex Offender Sentencing. Monitoring, apprehending, registering, and tracking. Office of Justice Programs, United States Department of Justice. https://www.ojp.usdoj.gov/smart/legislation.htm

Shelden R (2008) Controlling the dangerous classes: a history of criminal justice in America, 2nd edn. Pearson Allyn and Bacon, Boston

Shotter J (1993) Conversational realities. SAGE Publications Inc, London

Snyder H (2000) Sexual assault of young children as reported to law enforcement: victim, incident, and offender characteristics. U.S. Department of Justice, Washington, DC

Social K, Harris A (2016) Evaluating public perceptions of the risk presented by registered sex offenders: evidence of crime control theater? Psychol Public Policy Law 22(4):375

Spector M, Kitsuse J (1977) Constructing social problems. Cummings Publishing Company Inc, Menlo Park

Tennessee Board of Probation and Parole (2007) Monitoring tennessee's sex offenders using global positioning systems: a project evaluation. Retrieved November, 2010, from http://www.correcttechllc. com/uploads/document39.pdf

Tewksbury R, Mustaine E (2006) Where to find sex offenders: an examination of residential locations and neighborhood conditions. Crim Justice Stud 19(1):61-75

Tewksbury R, Jennings W (2010) Assessing the impact of sex offender registration and community notification on sex-offending trajectories. Crim Justice Behav 37:570-582

Tewksbury R, Jennings W, Zgoba K (2012) A longitudinal examination of sex offender recidivism prior to and following the implementation of SORN. Behav Sci Law 30:308-328

Tregilgas K (2010) Sex offender treatment in the United States: the current climate and an unexpected opportunity for change. Tulane Law Rev 84:729-757

Turner S, Jannetta J, Hess J, Myers R, Shah R, Werth R, Whitby A (2007) Implementation and early outcomes for the San Diego High Risk Sex Offender (HRSO) GPS Pilot Program. University of California, Irvine, Center for Evidence-Based Corrections, Irvine. https://ucicorrections.seweb.uci. edu/files/HRSO_GPS_Pilot_Program.pdf

Vanzile-Tamsen C, Testa M, Livingston J (2005) The impact of sexual assault history and relationship context on appraisal and responses to acquaintance sexual assault risk. J Interpers Violence 20:813-832

Vasquez B, Maddan S, Walker J (2008) The influence of sex offender registration and notification laws in the United States: a time-series analysis. Crime Delinq 54:175-192 
Veysey B, Zgoba K (2010) Sex offenses and offenders reconsidered: an investigation of characteristics and correlates over time. Crim Just Behav 37:583-595

Walker J, Golden J, VanHouten A (2001) The geographic link between sex offenders and potential victims: a routine activities approach. Justice Res Policy 3:15-33

Walker S (2006) Sense and non-sense about crime and drugs. Thomson Wadsworth, Belmont, CA

Wolak J, Finkelhor D, Mitchell K (2004) Internet-initiated sex crimes against minors: implications for prevention based on findings from a national study. J Adolesc Health 35(5):424.e11-424.e20

Wolak J, Finkelhor D, Mitchell K, Ybarra M (2008) Online predators and their victims: myths, realities and implications for prevention and treatment. Am Psychol 63:11-128

Yan Z (2006) What influences children's and adolescents' understanding of the complexity of the Internet? Dev Psychol 42:1-11

Zatz M (1987) Chicano youth gangs and crime: the creation of a moral panic. In: Kraska PB (ed) Theorizing criminal justice: eight essential orientations. Waveland Press Inc, Long Grove, pp 156-166

Zandbergen P, Levinson J, Hart T (2010) Residential proximity to schools and daycares: an empirical analysis of sex offense recidivism. Crim Justice Behav 37(5):482-502

Zevitz R, Farkas M (2000) The impact of sex-offender community notification on probation/parole in Wisconsin. Int J Offender Therapy Comp Criminol 44(1):8-21

Zgoba K, Witt P, Dalessandro M, Veysey B (2008) Megan's law: assessing the practical and monetary efficacy. A Research report submitted to the U.S. Department of Justice. https://www.ncjrs.gov/pdffi les1/nij/grants/225370.pdf

Publisher's Note Springer Nature remains neutral with regard to jurisdictional claims in published maps and institutional affiliations. 